\title{
ЗМІНИ РІВНЯ ПРОЛАКТИНУ У ЖІНОК ІЗ ДОБРОЯКІСНОЮ ПАТОЛОГІЕЮ МОЛОЧНИХ ЗАЛОЗ УПРОДОВЖ ВАГІТНОСТІ ТА ЛАКТАЦІЇ
}

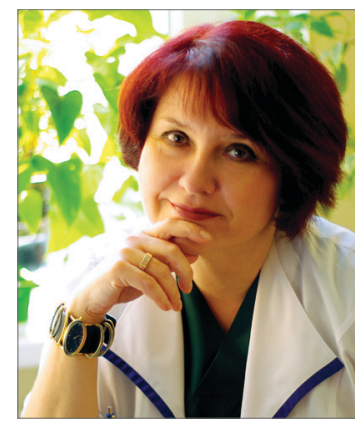

І.А. ЖАБЧЕНКО

д.мед.н., завідувач відділення патології вагітності та пологів Інституту педіатрії, акушерства та гінекології НАМН України

\section{3.Б. XOMIHCbKA}

д.мед.н. професор Інститут педіатрії, акушерства та гінекології НАМН України

\section{I.O. ШEKEPA}

Інститут педіатрії, акушерства та гінекології НАМН України
$\Pi$ ролактин $є$ ключовим гормоном, що контролює утворення грудного молока. У підготовці молочних залоз (МЗ) до лактації беруть участь й інші гормони, пептиди, фактори росту, вітамін D тощо [1-3]. Для росту протоків залоз необхідні естрогени, гормон росту та кортизон; для розвитку часточковоальвеолярної системи - естрогени, прогестерон і плацентарний лактоген; синтез протеїнів та жиру молока потребує наявності інсуліну та кортизолу. Проте для реалізації всіх цих процесів потрібна участь пролактину [4-6].

Високі концентрації естрогенів та прогестерону, що властиві для періоду вагітності, необхідні для розвитку МЗ. У той же час вони гальмують утворення молока шляхом блокування впливу пролактину на клітини МЗ. Одразу після пологів гальмівний ефрект стероїдних гормонів зникає внаслідок суттєвого зниження їхньої концентрації в крові, і починається лактація [2, 3, 7].

Згідно з літературними даними [8], лактогенез має дві стадії. Перша стадія починається в середині вагітності експресією генів, що кодують утворення протеїнів молока. Ця стадія в основному контролюється прогестероном, високий рівень якого запобігає розвитку другої стадії. У цей період вже може визначатися L-лактоглобулін [9]. Дія пролактину щодо лактогенезу є особливо суттєвою у другій стадії, що настає одразу після пологів і характеризується збільшенням продукції протеїнів молока, компактним з'єднанням епітеліальних клітин залози, зняттям блоку стероїдних гормонів та початком лактації через 2-4 доби після пологів [6, 8, 9].

Відомо, що рівень пролактину у жінок репродуктивного віку за умов фріброзно-кістозної хвороби МЗ змінюється [10, 11], проте дотепер особливості становлення лактаційної функції у цього контингенту хворих не вивчались. У той же час наявність дисгормональної патології МЗ та зв'язок її патогенезу із секрецією пролактину

ТАБЛИЦЯ 1

\begin{tabular}{|l|l|}
\hline Строк вагітності \\
\hline I триместр \\
\hline II триместр \\
\hline III триместр \\
\hline
\end{tabular}

Група

।

II

।

II

I

II
К-сть пацієнток

67

42

67

42

67

42
Пролактин, нг/мл

$104,5 \pm 10,5^{*}$

$66,3 \pm 8,3$

$201,2 \pm 15,8^{*}$

$123,6 \pm 16,1$

$254,6 \pm 20,3$

$242,7 \pm 19,1$
ТАБЛИЦЯ 1

РІВЕНЬ ПРОЛАКТИНУ В КРОВІ ЖІНОК ІЗ ФІБРОЗНО-КІСТОЗНОЮ ХВОРОБОЮ МЗ В ДИНАМІЦІ ВАГІТНОСТІ

* Різниця достовірна відносно відповідного показника у жінок другої групи; $p<0,05$ потребують спеціального дослідження динаміки продукції цього провідного гормона лактогенезу у пацієнток із фріброзно-кістозною хворобою МЗ.

Метою роботи було визначення особливостей секреції пролактину у жінок із фрібрознокістозною хворобою МЗ протягом вагітності та в період активного лактопоезу після пологів.

\section{МАТЕРІАЛИ ТА МЕТОДИ ДОСЛІДЖЕННЯ}

Визначення вмісту пролактину у крові проведено у 109 пацієнток у трьох триместрах вагітності. Із них у 67 учасниць першої (основної) групи дослідження було діагностовано фрібрознокістозну хворобу МЗ; 42 жінки не мали патології М3 (друга група). У 27 осіб (17 жінок першої групи та 10 другої) рівень пролактину в крові та грудному молоці було вивчено на 5-ту добу, а також через 3 та 6 міс після пологів. Забір крові з кубітальної вени та грудного молока проводили о 9-10.00 ранку натще, через півтори години після останнього годування дитини.

Концентрацію пролактину в сироватці крові визначали імуноферментним методом із використанням тест-системи. Отримані результати обчислювали за допомогою методів математичної статистики 3 використанням критерію Стьюдента.

\section{РЕЗУЛЬТАТИ ДОСЛІДЖЕННЯ ТА ÏХ ОБГОВОРЕННЯ}

Уміст пролактину в крові жінок обох груп протягом вагітності прогресивно підвищувався. Проте характер його секреції у пацієнток із фріброзно-кістозною хворобою МЗ суттєво відрізнявся від такого у вагітних без патології М3. Концентрація пролактину у сироватці крові у жінок основної групи у I та II триместрах вагітності достовірно була вищою, ніж у пацієнток групи порівняння (табл. 1). Цей показник в 1,6 разу був вищим, ніж у здорових жінок. У III триместрі концентрація пролактину в крові вагітних обох груп була однаковою.

Високий рівень пролактину в перші два триместри вагітності у жінок із фріброзно-кістозною хворобою МЗ міг негативно впливати на виношування вагітності - призводити до розвитку загрози її переривання, невиношування та передчасних пологів [12]. 3 іншого боку, за нашими спостереженнями, надмірні концентрації пролактину супроводжуються прогресуванням фріброзно-кістозноі хвороби МЗ у період вагітності [13]. У III триместрі вагітності значних змін секреції пролактину відносно норми у жінок першої групи не виявлено. 
БЕРЕМЕННОСТЬ И РОДЫ

На 5-6-ту добу після пологів концентрація пролактину в крові у пацієнток обох груп вірогідно знижувалася майже у два рази відносно показників у III триместрі вагітності (табл. 2).

Динаміка змін рівня пролактину через 3 та 6 міс після пологів у жінок із фріброзно-кістозною хворобою МЗ мала свої особливості. Так, у пацієнток другої групи (без патології МЗ) відбувалося поступове зниження вмісту гормона в сироватці крові із досягненням показників, характерних для невагітних жінок, через 6 міс після пологів - 15,6 \pm 3,9 нг/мл (норма для використаних тест-систем 1-25 нг/мл). У жінок із фіброзно-кістозною хворобою МЗ концентрація пролактину в крові через 5-6 днів і через 3 міс після пологів була достовірно співставною з групою порівняння, хоча мала певну тенденцію до зниження (в 1,1 та 1,3 разу відповідно). Через 6 міс цей показник, навпаки, суттєво перевищував як концентрацію гормона в крові жінок, що не мали захворювань МЗ (в 2,7 разу), так і референтні значення для діагностичних тестсистем, і становив 42,3 \pm 6,5 нг/мл (табл. 2).

Динаміка змін вмісту пролактину в грудному молоці жінок групи порівняння не відрізнялась від такої в сироватці крові, тобто цей показник був найвищим на 5-6-й день після пологів - 74,44 $\pm 8,1 \mathrm{нг} / \mathrm{мл}$; через 3 міс $-35,4 \pm$ 7,8 нг/мл та через 6 міс після пологів $-21,8 \pm 5,8$ нг/мл. Для жінок із патологією МЗ була характерна інша динаміка: у першому періоді обстеження на 5-6 день після пологів у них намітилась тенденція до зниження рівня пролактину в грудному молоці у порівнянні 3 пацієнтками другої групи (в 1,3 разу); через 3 міс після пологів спостерігалося достовірне його зниження (в 2 рази); через 6 міс, навпаки, з'явилася тенденція до його підвищення (в 1,6 разу) відносно цього показника в групі порівняння (табл. 2).

Варто зазначити певний паралелізм у змінах концентрації гормона в крові та грудному молоці у жінок із фріброзно-кістозною хворобою МЗ протягом періоду спостереження. Уміст гормона в крові був вищим, ніж у молоці, і співвідношення цих показників упродовж всього періоду дослідження не змінювалось (табл. 3). Існувала певна кореляційна залежність між рівнем пролактину у крові та в грудному молоці у жінок, що годують грудьми. Коефіцієнт кореляції у пацієнток із фріброзно-кістозною хворобою МЗ згідно із трьома періодами спостереження становив 0,49; -0,24 та 0,59 відповідно.

Концентрація пролактину в крові у пацієнток другої групи на 5-6-й день спостереження та через 3 міс після пологів також була вищою, ніж у грудному молоці. Через 6 міс після пологів у них намітилась тенденція до зниження співвідношення пролактин крові/ пролактин грудного молока до 0,71 \pm 0,19, що було пов'язано з достовірним зниженням концентрації гормона в крові (табл. 2, 3).

\begin{tabular}{|c|c|c|c|c|}
\hline \multirow{2}{*}{$\begin{array}{c}\text { Термін } \\
\text { спостереження } \\
\text { після пологів }\end{array}$} & \multirow[b]{2}{*}{ Група } & \multirow[b]{2}{*}{ К-сть пацієнток } & \multicolumn{2}{|c|}{ Пролактин, нг/мл } \\
\hline & & & Сироватка крові & Грудне молоко \\
\hline \multirow[t]{2}{*}{ 6-7-ма доба } & I & 16 & $109,3 \pm 9,6$ & $55,4 \pm 5,5$ \\
\hline & $\|$ & 10 & $123,5 \pm 21,0$ & $74,4 \pm 8,1$ \\
\hline \multirow[t]{2}{*}{3 мiс } & I & 16 & $28,2 \pm 6,6^{\star *}$ & $17,5 \pm 3,6^{* \star *}$ \\
\hline & ॥ & 10 & $36,2 \pm 7,9$ ** & $35,4 \pm 7,8^{* *}$ \\
\hline \multirow[t]{2}{*}{6 мiс } & I & 10 & $42,3 \pm 6,5^{*}$ & $35,4 \pm 6,0^{* *}$ \\
\hline & ॥ & 6 & $15,6 \pm 3,9$ ** & $21,8 \pm 5,8$ \\
\hline
\end{tabular}

Тенденція до зниження вмісту гормона у біологічних рідинах жінок із фріброзно-кістозною хворобою МЗ у період завершення лактогенезу та достовірне зниження рівня пролактину в грудному молоці через 3 міс лактації свідчать про загрозу розвитку гіпогалактії у даного контингенту жінок, що годують грудьми.

3 огляду на роль пролактину у розвитку гіперпластичних процесів репродуктивних органів, більш високий його рівень у крові та грудному молоці жінок першої групи через 6 міс після пологів, ніж через 3 міс та відносно жінок другої групи, може сприяти підтримці та подальшому розвитку у них патологічного процесу МЗ.

ТАБЛИЦЯ 3.

\begin{tabular}{|l|c|c|c|}
\hline $\begin{array}{c}\text { Термін } \\
\text { спостереження } \\
\text { після пологів }\end{array}$ & Група & K-сть пацієнток & $\begin{array}{c}\text { Співвідношення } \\
\text { концентрації } \\
\text { пролактину в крові } \\
\text { та грудному молоці }\end{array}$ \\
\hline 6-7-ма доба & I & 16 & $1,73 \pm 0,16$ \\
\hline 3 міс & $\|$ & 10 & $1,68 \pm 0,29$ \\
\hline 6 міс & I & 16 & $1,92 \pm 0,38^{\star}$ \\
\hline & I & 10 & $1,02 \pm 0,10$ \\
\hline
\end{tabular}

\section{ВИСНОВКИ}

1. Концентрація пролактину в крові вагітних за умов фріброзно-кістозної хвороби МЗ суттєво відрізняється від такої у жінок без патології М3, що проявляється достовірним підвищенням рівня гормона в їх крові в I і II триместрах вагітності та його нормалізацією у III триместрі.

2. Динаміка змін вмісту пролактину в крові і грудному молоці у пацієнток із фрібрознокістозною хворобою МЗ упродовж перших 6 міс лактації має свої особливості порівняно зі здоровими жінками: тенденцію до зниження рівня гормона в біологічних рідинах через 5-6 днів та 3 міс після пологів та до його підвищення через 6 міс спостереження. Такі зміни секреції пролактину у жінок із фріброзно-кістозною хворобою МЗ можуть сприяти невиношуванню вагітності, розвитку гіпогалактії та прогресуванню патології МЗ.

Список літератури у кількості 13 джерел представлений на сайті: www.reproduct-endo.com.ua
ТАБЛИЦЯ 2 КРОВІ ТА ГРУДНОМУ МОЛОЦІ У ЖІНОК ІЗ ФІБРОЗНО-КІСТОЗНОЮ ХВОРОБОЮ МЗ У РІЗНІ СТРОКИ ЛАКТАЦІЙНОГО ПЕРІОДУ

* Різниця достовірна відносно відповідних показників жінок другої групи; $p<0,05$

* Р Різниця достовірна відносно відповідних показників на 6-7-му добу життя; $p<0,05$
СПІВВІДНОШЕННЯ КОНЦЕНТР ПРОЛАКТИНУ В КРОВІ ТА ГРУДНОМУ МОЛОЦІ У ЖІНОК НА РІЗНИХ СТРОКАХ ЛАКТАЦІЙНОГО ПЕРІодУ * Різниця достовірна відносно відповідних показників першої групи; $p<0,05$

* Р Різниця достовірна відносно відповідних показників на 6-7-му добу після пологів; $p<0,05$ 